\title{
Introduction and Assessment of a Socio-Economic Mine Closure Framework
}

\author{
André Xavier ${ }^{1}$, Marcello M. Veiga ${ }^{1} \&$ Dirk van Zyl $^{1}$ \\ ${ }^{1}$ Norman B. Keevil Institute of Mining Engineering, University of British Columbia, Vancouver, BC, Canada \\ Correspondence: André Xavier, Mining Engineering Department, University of British Columbia, V6T 1Z4, \\ Vancouver, BC, Canada. Tel: 1-604-822-5252. E-mail:andre.xavier@ubc.ca
}

\author{
Received: December 27, 2014 Accepted: January 19, 2015 Online Published: February 20, 2015 \\ doi:10.5539/jms.v5n1p38 URL: http://dx.doi.org/10.5539/jms.v5n1p38
}

\begin{abstract}
This paper introduces and assesses the Socio-Economic Mine Closure Framework. The Framework assessment included an online survey distributed to 151 experts, and a field investigation, conducted in Mongolia, in which the local community was invited to participate. A key objective of the case-study was to identify and assess the community investment initiatives implemented by a mining company. The fieldwork also aimed to assess the perceptions of local residents about the success of these initiatives. The study indicates that it would be relevant, timely and appropriate for the mining industry to adopt the proposed Framework. The case-study analysis found that several initiatives were implemented and supported by the company, but that the company's relationship to local governments was deemed to be too close and as such, was found to overshadow many of its initiatives. This situation resulted in a lack of awareness on the part of local residents regarding the community investments made by the company. Some of the programs available to the community, such as the microcredit program, would need to be reviewed because of a lack of transparency and limited accessibility. Furthermore, local residents expect a greater focus on the development of small businesses and job creation. The engagement and participation of local residents is limited, andlocal residents want to have a say in the decisions that affect the community.
\end{abstract}

Keywords: community participation, socio-economic, mine closure, sustainable development

\section{Introduction}

Mines close either when resources become depleted or when it becomes unfeasible, from an economic standpoint, to keep mining. At the time of closure, it is typical that a well-deserved environmental concern develops to mitigate and reclaim the disturbed areas. However, very little attention is usually focused on the socio-economic impacts that the closure of a mine imposes on governments, and especially on communities (Veiga et al., 2001, Kemp et al., 2008). Even in cases where the closure plan contemplates social dimensions, the approach is usually not well articulated, and does not consider the implementation of comprehensive and sustainable initiatives that would allow local communities to overcome the wide range of consequences brought on by the withdrawal of resources when a mine ceases its operations.

Corporate Social Responsibility (CSR) initiatives have become a common practice in the mining industry, and CSR is now part of the business strategy for most companies. CSR initiatives have claimed to support community development while at the same time prepare communities for closure. However, the approach undertaken has very often been focused on building infrastructure facilities, which the communities are then not able to maintain subsequent to closure (Roberts \& Veiga, 2000). This paper comprises of an exploratory case study that focuses on the efforts undertaken by Boroo Gold Company (BGC), a Mongolian mining company, towards implementing initiatives to cope with the social and economic impacts of mine closure. Based ona review of voluntary and required industry-related guidelines and previous fieldwork, a framework has been developed as a Socio-Economic Mine Closure (SEMC) management tool. Despite the efforts undertaken to promote integrated mine closure frameworks and guidelines (e.g. Planning for Integrated Mine Closure Toolkit, and the MMSD Mine Closure Working Paper) by the resource extractive sector and international organizations, the existing approach still focuses heavily on environmental matters. When it considers the social dimensions, this approach is "confined to the inclusion of stakeholder consultation (Chaloping-March, 2008) and tends to lack initiatives to properly deal with the social and economic impacts that closing a mine imposes on local 
governments and communities. Paradoxically, government response to the social and economic problems brought on by mine closure has typically been passive. This approach is illogical because towards the end of a mine's working life, the heavy burden of the closure will inevitably impact on governments.

Mining companies have historically understood mine closure as involving the processes of mine site rehabilitation and decommissioning. Furthermore, the general belief within the industry is that by being in compliance with the law, paying taxes, doing philanthropy and implementing social projects, companies are exempt from further responsibility in relation to the socio-economic impacts that the closure of the mine will have on local communities and governments. Multiple international and industry-related initiatives such as the Equator Principles, Towards Sustainable Mining, Planning for Integrated Mine Closure Toolkit, and the MMSD Mine Closure Working Paper have been implemented. Many of these touch upon the socio-economic aspects of mine closure. Nevertheless, gaps still remain and no comprehensive, integrated planning and implementation processes have yet been proposed. One of the focal arguments in this paper is that a refined and integrated management process, as well as appropriate leadership skills all need to be developed for a comprehensive socio-economic mine closure to take place.Several authors (Clark \& Clark, 1999; Roberts \& Veiga, 2000; Veiga et al., 2001; Chaloping-March, 2008; Kemp et al., 2008; van Zyl, 2010) have pointed out the importance of a more comprehensive and holistic approach to mine closure. For them, the manner of engaging with communities and helping them cope with the social dimensions and the socio-economic impacts of a mine closure on individuals and communities needs to be properly taken into account.

In this context, mine closure should consider a more holistic approach that is aimed atdeveloping and supportingthe implementation of a plan that contributes to minimizing and avoiding the direct socio-economic impacts that closing a mine imposes on governments and local communities, and it should make contributions to the sustainable development of these regions.

\section{Socio-Economic Mine Closure (SEMC) Framework}

Mine closure is a process for which the ultimate goal is to prevent or minimize adverse environmental, physical, social and economic impacts (Australian Government - Department of Industry, Tourism and Resources, 2006, ICMM, 2008). Furthermore, "the future of the mining industry is dependent on the legacy it leaves" (Australian Government - Department of Industry, Tourism and Resources, 2006). In the earlier pages of the ICMM IntegratedMine Closure Planning Toolkit, it becomes evident that in addition to minimizing that adverse impacts,the document is intended to "support an operation in achieving a post closure status that leaves behind an enduring positive legacy in the community" (2008).

In this context, mine closure can be fundamentally linked to community development. Community Development (CD) consists of the (planned) evolution of several aspects of community wellbeing (economic, social, psychological, environmental, cultural and political), and community wellbeing is achieved through reaching an equilibrium between accessible resources and the challenges faced by community members (Dodge et al., 2012). As such, community development becomes a process whereby people come together to take collective action to successfully solve common problems, as well as implement changes at the local level in order to enhance the quality of life of community members (Frank \& Smith, 1999; Maser, 1997).

Community Development involves a self-assessment to plan for the future. Central to this is the belief that members within the community have the primary responsibility for decision-making and action (Homan, 1999).

Although industry and government guidelines highlight the importance of an integrated approach to mine closure, one of the deficiencies of industry-related guidelines in dealing with the socio-economic consequences of the mine closure is that they do not properly consider the importance of leadership. Additionally, initiatives for building local capacity lack integration and tend to be limited, as in the case of education programsthat focus on the development of professional and technical skills instead of on the promotion of a well-rounded education. Aggravating the situation, short-sighted philanthropic initiatives and paternalistic attitudes seem to be ingrained in the cultures of both communities and companies. Such initiatives can have positive impacts in the short-term, but when not adequately planned for and implemented, they can lead to an unsustainable environment that produces dependency and the lack of initiative and creativity - all of which ultimately impact negatively on the community.Successful socio-economic mine closure demands refined management and leadership skills, and needs to be implemented as an integrated, comprehensive and multifaceted process. Table 1 outlines a conceptual framework of ten elementsand sub-elements for Socio-Economic Mine Closure that take management and leadership elements into account. 
Table 1. Socio-Economic Mine Closure (SEMC) Framework

\begin{tabular}{|c|c|c|}
\hline Element & Sub-Element & Description \\
\hline \multirow[b]{2}{*}{ 1. Policy } & $\begin{array}{l}\text { Corporate } \\
\text { Commitment }\end{array}$ & $\begin{array}{l}\text { Corporate commitment to SEMC can only be enduring if it is embraced, promoted and } \\
\text { supported by corporate management, including the Board of Directors, CEO, COO and } \\
\text { the CFO. This commitment must be communicated through corporate values, policies, } \\
\text { actions and performance measures. }\end{array}$ \\
\hline & Governance 360 & $\begin{array}{l}\text { In the context of SEMC, corporate governance is used to indicate a situation where all } \\
\text { levels of corporate management take into account their responsibilities to a broad range } \\
\text { of stakeholders, not just shareholders making decisions. It is also of benefit to all } \\
\text { stakeholders if the corporation encourages / promotes similar behaviour towards } \\
\text { communities and governments at all levels. }\end{array}$ \\
\hline
\end{tabular}
communities and governments at all levels.

Mining companies need to have one or more representatives physically present in the

Presence in the field about mining, need to be familiar with the realities and subtleties inherent in the field and in the community. It would be preferable to have a local resident or someone who has lived in the area to lead the team on behalf of the company.

2. Presence Stakeholder analysis involves the identification of groups and individuals who are affected and who can influence a mining project. This involves developing an understanding of who they are, their needs, wants, level of power of influence and Stakeholder Analysis support for a given project. This approach providesthe foundation for a better understanding of all the peoples affected by a mining project, and it is critical tomaking information available when designing and implementing strategies to address the socio-economic impacts of mine closure.

Mobilization is the initial stage in developing meaningful community participation and engagement. Here, information is shared, community leaders are approached, and the

Mobilization overall community is made aware of the importance of their participation in planning and implementing changes that will address the socio-economic impacts of mine closure.

Paideia was the word used by the ancient Greeks to define education. To them, paideiainvolveda long-term process of gaining a well-rounded education which went beyond learning a trade or an art. It is through such a holistic approach to education Education / Capacity that mine closure should be approached. Clearly, this should not exclude the adoption Building of programs that would promote the development of technical / professional skills. In fact, a well-rounded education which includes training programs will be the foundation through which to build capacity not only within communities, but also for the company, government and other stakeholders.

\section{Participation} Empowerment is defined by the World Bank as expansion of freedom of choice and action, which in the context of the SEMC Framework, can be translated as ensuring that community members and other stakeholders are able to freely participate, make

Empowerment suggestions, and raise concerns in relation to issues associated to a mining project. Furthermore, empowerment opens up opportunities for action and participation which, in addition to supporting community engagement, can enhance the community's sense of ownership.

Community engagement involves a process of supporting, building, and maintaining Community collaborative relationships with stakeholders, and local community members. In Engagement addition, community engagement is also fundamental for creating a sense of ownership and belonging between community members, and is critical for planning and implementing community projects.

The establishment of strategic, tactical and operational partnerships with key players

Partnerships (e.g. government, communities, NGO, other companies) are critical for community development and managing the challenges that closing a mine brings to local governments and communities.

Asset Mapping is a participatory process that involves inventorying and assessing the natural and physical characteristics of a community. Additionally, through taking an inventory of the capabilities and interests of individuals, civic groups and other

4. Planning Asset Mapping institutions, the social, cultural and economic assets of a community are mapped and evaluated. The information produced from the Asset Mapping process is critical, not only for the planning phase, but also in the participation step as it also functions towards mobilization, education, and the creation of community engagement tools. 
Socio-Economic Impact Assessment SEIA

Project Design

Performance

Indicators

Resources

Socio-economic impact assessment provides a clearer understanding of the social, cultural and economic effects of mining activities on local stakeholders. This, in turn, is key in the process of planning, implementing and evaluating initiatives to effectively address these effects.

Developing a clear and compelling vision of the ideal community is a critical step in the planning process. In the course of developing a vision, a collective process is demanded wherein the company, local government and most importantly, the local community, establish the things they would like to change and / or preserve in the community.

Using information drawn from the asset mapping and socio-economic impact assessment phase, projects will be designed to bring about the changes the community wants to see. This will take place using the vision developed by the community.

As a final step in the planning phase, it is important to define performance indicators to measure performance and to evaluate the results of the implemented actions and projects.

The allocation of proper financial and technical resources is a basic step that enables diagnostics, planning, implementation and the evaluation of initiatives to address the socio-economic impacts of the closure. At this point, it is critical to underscore that although mining companies are a key player in identifying and allocating resources, communities and governments also bear some responsibilities.

\begin{tabular}{l} 
Implementation \\
Monitoring \\
\hline
\end{tabular}

Implementation refers to the process of carrying out the established strategies and putting the projects designed in the planning phase into practice.

Monitoring refers to the application of systematic observation, as well as the regular collection of information and the use of measurement-taking procedures.

5. Performance Evaluation Towards monitoring stage. The knowledge originated in the evaluation phase will assist in Continuous assessing the contribution and effectiveness of the strategies and projects that have Improvement been implemented. Additionally, this information will also be used to enhance performance, thus allowing for continuous improvement.

\begin{tabular}{|c|c|c|c|}
\hline \multirow{2}{*}{6.} & \multirow{2}{*}{ Promotion } & $\begin{array}{l}\text { Sharing } \\
\text { Communication }\end{array}$ & $\begin{array}{l}\text { Refers to a process of effective communication whereby information is shared with all } \\
\text { interested parties about the strategies, status and outcomes of the initiatives as they } \\
\text { relate to the socio-economic aspects of mine closure. }\end{array}$ \\
\hline & & Consolidation & $\begin{array}{l}\text { Consolidation, in the context of SEMC, refers to the process of ensuring that the } \\
\text { successful strategies and procedures adopted to address the socio-economic impacts of } \\
\text { mine closure are incorporated into both the community's and company's cultures. }\end{array}$ \\
\hline \multirow[b]{2}{*}{7.} & \multirow[b]{2}{*}{ Perseverance } & $\begin{array}{l}\text { Overcoming } \\
\text { Resistance and Inertia }\end{array}$ & $\begin{array}{l}\text { Perseverance acts as an antidote against the initial resistance and inertia that people } \\
\text { may present regarding changes. }\end{array}$ \\
\hline & & $\begin{array}{l}\text { Reinforcing Quality of } \\
\text { Participation }\end{array}$ & $\begin{array}{l}\text { Perseverance is also seen as an opportunity for enhancing community participation and } \\
\text { engagement, not only in relation to the number of participants, but also with regard to } \\
\text { the quality of participation. }\end{array}$ \\
\hline 8. & Patience & $\begin{array}{l}\text { Allowing Time for } \\
\text { Effective Change }\end{array}$ & $\begin{array}{l}\text { Social intervention requires time to produce significant results, thus patience becomes } \\
\text { an important element. Patience refers to the ability to allow enough time for meaningful } \\
\text { changes to take place. }\end{array}$ \\
\hline 9. & Passion & $\begin{array}{l}\text { Individual Passion / } \\
\text { Motivation }\end{array}$ & $\begin{array}{l}\text { Several authors see passion as the driving force for successful community } \\
\text { development. Both community members and the company's representatives need to be } \\
\text { motivated and passionate about community change and development. Passion is seen as } \\
\text { a trait that can be passed onto other people and provides the strength and perseverance } \\
\text { needed to bring about the changes necessary for successful community development. }\end{array}$ \\
\hline 10. & Personality & $\begin{array}{l}\text { Trust, Respect and } \\
\text { Empathy }\end{array}$ & $\begin{array}{l}\text { Personality is defined as the combination of traits, characteristics and qualities that } \\
\text { distinguishes an individual. In the context of SEMC, trust and respect are } \\
\text { fundamental personality characteristics that should be exhibited by the company's } \\
\text { representatives and fostered within all stakeholders. These traits create the likelihood } \\
\text { for people to engage genuinely and to collaborate with each other, and are therefore } \\
\text { critical for the successful planning, implementation and evaluation of initiatives that } \\
\text { aim to address the social and economic impacts of mine closure. } \\
\text { Additional to trust and respect, another fundamental characteristic that plays a role in } \\
\text { the company-community relationship is empathy. Empathy is the ability to understand, } \\
\text { and to some extent to share feelings that are being experienced by other people. } \\
\text { Empathy is key to showing care and building respect and trust. }\end{array}$ \\
\hline
\end{tabular}




\section{Assessment of the SEMC Framework}

The proposed framework was developed as a result of theauthors' fieldwork experiences as well as theirreview of existing key industry-related guidelines (Note 1). Furthermore, an online survey was conductedin order to gainanother perspective from whichto assess the proposed SEMC Framework. The aim in this phase was to assess, refine and receive feedback on the SEMC Framework. The question of interest centered onwhether the proposed Framework, its elements and sub-elements make sense, not only to the researchers, but to other practitioners and scholars. Does the SEMC Framework present a reasonable theory for scholars studying the subject? Do the order and importance of the elemental components of the Framework make sense? With these questions in mind, the SEMC Framework was presented to mining professionals working in the fields of sustainability and community development, as well as to other professionals such as consultants and NGO affiliates. These key experts were asked to provide feedback and insights on the Framework through an online survey. Furthermore, scholars who are known to be actively involved in the area of community relations, community development and community sustainability were also approached for the same purpose.

The identification of the online survey participants was made based on interactions between the authors and potential survey participants in the previous two years prior to the distribution of the research. This was made possibleas a result of the authors' attendance at several academic and industry-related conferences and events.

A total of 169 people were invited to participate in the online survey. These individuals were classified according to 5 different categories which were related to their professional connections: Industry, Education, NGO, Consultant and Government. Represented in the Education category were professors and graduate students who work and/or research topics in the mining sector. From the total of all the online invitations sent out, 18 emails bounced back, resulting in 151 successful invitations. Of these, 99 responses to the online survey were received back, resulting in a $66 \%$ response rate. The percentages of respondents by category were: Industry (36\%), Education (33\%), NGO (11\%), Consultant (12\%), and Government (07\%) (Note 2).

The online survey participants were from 16 countries including Canada, United States, Mexico, Ecuador, Brazil, Peru, Australia, Indonesia, Mongolia, Kenya and Spain. They consisted of individuals who work in the field of mining, and who are directly involved with at least one or more constituent elements of the SEMC Framework. There were three main objectives for distributing the online survey: 1) to assess how the SEMC Framework is perceived by the different Groups/Categories; 2) to rank the 10 constituent elements of the SEMC Framework in order of importance, and 3) to solicit feedback and comments on the overall SEMC Framework. In order to rate the elements according to order of importance, the online research subjects were asked to rank the elements from 1 to 10, where higher scores indicated higher importance and lower scores indicated lower importance. The respondents could also assign the same score to more than one element, a situation that was in fact observed. Table 2 below has beencompiled to depictparticipants' average scores and standard deviations.

Table 2. Average scores and standard deviation responses — online survey participants

\begin{tabular}{lllllllllll}
\hline Elements & Industry & St.Dev & Educ & St.Dev & NGO & St.Dev & Consult & St.Dev & Govnt & St.Dev \\
\hline Participation & 9.38 & 0.95 & 9.31 & 1.06 & 9.40 & 1.20 & 8.20 & 3.12 & 9.00 & 1.78 \\
Passion & 5.95 & 2.20 & 6.00 & 2.34 & 7.60 & 1.49 & 4.60 & 1.35 & 6.75 & 2.58 \\
Patience & 7.33 & 1.88 & 7.85 & 1.51 & 8.40 & 1.20 & 5.80 & 2.03 & 7.36 & 1.66 \\
Performance & 8.43 & 1.49 & 8.54 & 2.30 & 9.20 & 0.74 & 8.40 & 3.20 & 9.58 & 0.49 \\
Perseverance & 7.33 & 1.78 & 6.54 & 2.37 & 7.60 & 2.57 & 7.20 & 1.93 & 7.92 & 1.97 \\
Personality & 6.65 & 2.30 & 6.67 & 2.35 & 7.20 & 1.93 & 5.40 & 3.00 & 7.08 & 2.66 \\
Planning & 8.86 & 1.93 & 8.75 & 1.73 & 8.00 & 0.89 & 7.80 & 3.48 & 8.67 & 1.34 \\
Policy & 8.43 & 1.43 & 7.31 & 3.19 & 8.20 & 1.16 & 7.00 & 2.68 & 9.08 & 1.20 \\
Presence & 8.19 & 1.84 & 7.92 & 2.73 & 7.00 & 1.00 & 5.80 & 2.71 & 7.92 & 2.09 \\
Promotion & 7.43 & 2.21 & 7.08 & 2.52 & 7.00 & 3.34 & 6.80 & 2.92 & 7.50 & 2.17 \\
\hline
\end{tabular}

Although some similarities can be identified, as in the example thatIndustry and Education groups both consideredthat Participation, Planning and Performance werethe most important elements in the SEMC Framework, there is no consensus between these groups regardingthe order and weight of the proposed Framework. Table 2 is displayed in alphabetical order.Multiple comparison tests were conducted between the constituent elements of the SEMC Framework and the five different groups. Significant differences were found only in the element Passion (p-value 0.03) when compared NGO and Consultant's average responses, and in the responses for the element Presence ( $\mathrm{p}$-value 0.03 ) when compared the average responses between the Industry 
and Consultant groups. Descriptive analysis of the responses is a useful tool through which to shed light on how people pertaining to these five groups see the elements of the SEMC Framework. Additionally, during the description analysis, some of the comments provided by the online survey participants wereadded to provide further explanation about their perceptions.

\subsection{Industry Category}

According to the 36 responses received from the category Industry, the element of Participation is the most important $(\mathrm{AV}=9.38 ; \mathrm{SD}=0.95)$, followed by Planning $(\mathrm{AV}=8.86 ; \mathrm{SD}=1.93)$, and Policy $(\mathrm{AV}=8.43 ; \mathrm{SD}=$ $1.43)$ and Performance $(\mathrm{AV}=8.43 ; \mathrm{SD}=1.49)$. According to this group, the two least important elements are Personality $(\mathrm{AV}=6.65 ; \mathrm{SD}=2.30)$ and Passion $(\mathrm{AV}=5.95 ; \mathrm{SD}=2.20)$.

Some individuals from the category Industry also provided additional comments. These comments, such as "No one element is conclusive. It is the sum of them that makes the difference" (Industry 1), are relevant because they express the complexity that is involved in mine closure. Another important comment was made by a participant regarding the element Promotion; "in community relationship building, celebrating the successes - big and small (and on an on-going basis) is a great way to encourage all the other aspects: participation, passion, etc." (Industry 15). This comment speaks tohow the elements in the Framework are intertwined.With respect to the element Promotion, another Industry respondent pointed out that companies should "be honest rather than chasing the truth $[\ldots]$. Establishing trust and building and maintaining relationships are more about the discussion and less about the details" (Industry 23).

\subsection{Education Category}

It is noteworthy that the responses from the Industry and Education category groups reveal strong correspondences. The 33 individuals who comprised the Education group ranked Participation ( $\mathrm{AV}=9.31 ; \mathrm{SD}=1.06)$, Planning (AV $=8.75 ; \mathrm{SD}=1.73)$ and Performance $(\mathrm{AV}=8.54 ; \mathrm{SD}=2.30)$ as the most important elements in the SEMC Framework. The responses from the Industry category were strikingly similar: Participation $(\mathrm{AV}=9.38 ; \mathrm{SD}=$ 0.95), Planning $(\mathrm{AV}=8.86 ; \mathrm{SD}=1.93)$ and Performance $(\mathrm{AV}=8.43 ; \mathrm{SD}=1.49)$. Furthermore, those from within Education ranked Presence $(\mathrm{AV}=7.92 ; \mathrm{SD}=1.84)$ as the $4^{\text {th }}$ most important element. Finally, Personality and Passion were ranked as the $8^{\text {th }}$ and $10^{\text {th }}$ elements in order of priority for the Education respondents.

One of the respondents from the Education group underscored the importance of community participation in the process as "the community's role in mine closure remains unclear and is often still largely dependent on the company's commitment (resources) to a sustainable closure plan" (Education 1).

This situation was identified during the Mongolian fieldwork, where community members made the criticism that mining companies should create more opportunities for the community to participate in the decision-making process. It was however noted that a passive mentality existed in-as-much as community members tended to criticize, but did not take initiative towards changing the situation, and also did not express clear ideas regarding how participation towards change could take place.

\subsection{NGO Category}

In relation to the responses provided by the 11 individuals belonging to the NGO category, it was noted that the respondents placed high importance on all the elements that constitute the SEMC Framework. Participation (AV= 9.40; $\mathrm{SD}=1.20)$ and Performance $(\mathrm{AV}=9.20 ; \mathrm{SD}=0.74)$ were however the most important elements for this group. Two elements that deserve some attention are Planning $(\mathrm{AV}=8.00 ; \mathrm{SD}=0.89)$ and Patience $(\mathrm{AV}=8.40 ; \mathrm{SD}$ $=1.20$ ). Planning was rated $5^{\text {th }}$ in terms of importance, and Patience was ranked as $3^{\text {rd }}$. Patience, in this context, has been defined as the ability to allow enough time for meaningful social and economic changes to take place. Particularly with respect to social and economic change, community projects need time to yield significant results. One NGO representative commented on the importance of Patience: "I like your proposition of patience in the Framework. Typically companies, governments and local communities underestimate the time required for changes to happen, resulting in frustration to all involved" (NGO 1). Local governments for instance, tend not to think beyond their $4-5$ year terms and try to reap the benefits of mining projects as soon as possible. Similarly, mining companies strive to demonstrate that tangible benefits have been delivered to the host communities as of the early stages of the mine's life cycle. As result, short-term projects that focus on building infrastructure facilities have become the common approach. The aim of the discussion is not to stop short-term and infrastructure initiatives, rather the task is to find a balance between delivering important and badly needed short-term projects, with initiatives that require a longer time to produce results. The importance of community participation and organization was also expressed by a respondent from an NGO who said that, "all components [in the Framework] are highly relevant. A successful case [for mining closure] may imply a lead of the community on the post closure 


\section{vision and land use planning" (NGO 5).}

\subsection{Consultant Category}

Maintaining presence in the community, fostering dialogue, promoting participation and building trust are critical to the success of any community development work (Veiga et al., 2001; Homan, 2004).

It is surprising to note that those in the category of "Consultant" ranked the element Presence in the $9^{\text {th }}$ position in terms of importance. In fact, when compared to the other four groups (Industry, Education, NGO and Government) which placed Presence higher, those in the Consultant category assigned the elements of Presence (AV $=5.80 ; \mathrm{SD}$ $=2.71)$ and Personality $(\mathrm{AV}=5.40 ; \mathrm{SD}=3.00)$ the two lowest scores. Because the nature of community development requires active fieldwork involving the promotion of dialogue and engagement with the local citizens, it would be expected that the Consultant group would have assigned Presence a much higher score. These findings, in fact, point to some of the challenges regarding the element Presence in community development. As such, Presence is not only an issue that of concern toconsultants in the field of mining, but it is also highly relevant to a variety of professionals who hold responsibilities in supporting community development, particularly in rural and remote regions.

One of the challenges of community development in mining relates to community access, since many mining communities are located in regions with rudimentary or non-existent access roads. Some of them are only reachable by boat or airplane. In addition, many of these communities lack basic infrastructure such as adequate housing and/or potable water.These challenges render Presence within the community more difficult for mining companies. Nevertheless, in their effort to improve this situation, some companies are creating community liaison positions whose basic role involves sharing and disseminating information, and providing feedback on community-company related affairs to both the mining company and the community. However, the existence of a community liaison representative does not eliminate the importance of having company officials, particularly those who have decision-making authority, having a concrete presencein the community. This situation was observed in the Mongolian case study where, after the community liaison positions had been created, the company community relations manager was noted to have reduced his presence in the community. The following quote summarizes the above discussion, "Presence is for me the single most important fact for a successful mine closure. People need to confirm that the company is there, close and caring about their future" (Industry 17).

\subsection{Government Category}

Performance $(\mathrm{AV}=9.00 ; \mathrm{SD}=0.49)$ and Policy $(\mathrm{AV}=9.00 ; \mathrm{SD}=1.20)$ were considered the most important elements in the SEMC Frameworkfor the Government affiliates. It is interesting to note that Planning ( $\mathrm{AV}=8.67$; $\mathrm{SD}=1.34$ ) was ranked in the $7^{\text {th }}$ position of importance. With regard to overall Planning, one important issue identified in many mining communities relates to how the moneys provided by the mining companies are invested. For obvious reasons, mining companies and local governments tend to keep very close relationships and it is a common approach for mining companies to set up donation funds and financial compensation to support local development and improve the quality of life in the host communities. However,lack of participation and transparency regarding the use of the funds provided by the company, as well asafocus on short-term projects (e.g. construction of a sports center) to thedetriment of longterm ones seems to be a common issue, as identified in the Mongolian case study which will be furtherdiscussed in the following section. As a result of this situation, communities commonly experience a variety of challenges when the flow of money ceases, and both governments and communities are forced to adjust to decreases in quality of life and increases in costs for maintaining the facilities that have been built over the course of the mining project.Many community members are awarethe challenges of such a shortsighted approach. During the fieldwork, some study participants were vocal in speaking to the needhigher levels of community participation, as well as greater transparency regarding the use of the money.

\section{Mongolian Case Study}

Boroo Gold Company (BGC) owned by Centerra Gold is an open-pit gold mine in Mongolia that is located about $150 \mathrm{~km}$ northeast of the capital Ulaanbaatar. It was the first hard-rock gold mine established in Mongolia, and the largest foreign investment in the country at the time it began production in 2004. The mine has produced more than 1.5 million ounces of gold (Centerra Gold, 2009). Due to the exhaustion of its economically viable ore, it temporarily stopped mining at the end of 2010. In 2011, BGC began to process its stockpiled ore, and in 2012 it was granted a license to re-start heap leaching of the stored low-grade ore. Additionally, as a result of the high price of gold which makes mining this type of low-grade ore economically viable, the company restarted mining some small deposits in 2012. In spite of currently being in production, the lifespan of the BGC mine is destined to be short and although no exact closing date has been set, it is estimated that operations will continue until 2015. At its 
peak, BGC had 800 employees, although the mine currently employs only around 300 people, of whom $97 \%$ are Mongolian citizens (Centerra Gold, 2012).

Boroo mine is located in two separate soumsin Selenge province. The open pits and mill facilities are located in Bayangol and the tailing dams, power line and wells that supply water to the mine are located in Mandal soum.Mandal soum has 25,000 inhabitants,amongwhich 28 people are employed by the mine. Bayangol soum has 5,000 inhabitants, of which 120 people are currently working at the mine.

Centerra holds a mine license in Gatsuurt, which is located in Mandal soum, $35 \mathrm{~km}$ to the east of the Boroo mine. Since Gatsuurt is located near the BGC mine site, Centerra's plan is to use the milling facilities at Boroo to process the Gatsuurt ore, which would extend the closing process of the Boroo site for another 10 years. The Gatsuurt project has obtained all the licenses needed to initiate operations, but a prohibition of mineral exploration in water basins and forest areas (as a result of the passing of the 2009 Water and Forest Law) has put the Gatsuurt and many other hard-rock projects on hold since they are situated in areas that are regulated by this Law.

Since 2004, as part of its policy of engaging with local governments and communities, Boroo has created and committed to donating USD \$250,000 every year to the Soum Development Fund (SDF). Mandal, Bayangol and the Selenge province each receive this amount annually for the SDF. In addition, a one-time USD \$40,000 Microcredit Fund was also given to both Mandal and Bayangol soums with the aim of supporting the development of small businesses in those communities. In total, to date BGC has donated over USD 5 million dollars to the province and the two soums. The SDF is managed by a Joint Working Group (JWG) which is formed by soum and bagh (Note 3) government officials, and other UB-based BGC management personnel. In principle, the JWG decides on the priorities for the soum and determines where the SDF should be invested.

Another initiative implemented by BGC in 2010 with the aim of improving its relations with, and increasing its presence in the community was the creation of the position of the Community Relations Officer (CRO). The CRO's main duty is to function as a liaison between the company and the community. Bayangol has one CRO, and two CROs were appointed for Mandal. Mandal is the largest soum in the country, with more than 25,000 inhabitants. In addition to mining, other major industrial and economic activities include a spirit factory that produces vodka, a brick factory, and the railway station.The region is generally agricultural, and both Mandal and Bayangol have high participation rates in farming activities, with many families operating economic gardens out of their backyards. As is true for virtually all Mongolian regions, herding also plays a significant role in both Mandal and Bayangol. Herding is a significant economic activity which resultsin the production of milk, wool and cashmere.Other than mining, there is no major industry in Bayangol.

\subsection{Case Study Methodology}

After assessing the SEMC Framework through the online survey, a fieldwork was arranged and conducted in Mongolia. The objective of this fieldwork was to assess the initiatives implemented by the mine company and to capture the perceptions of local residents in relation to these initiatives.

A thirteen day field visit to Ulaanbaatar, Mandal and Bayangol soums (Note 4) was undertaken in order to gain a better understanding of the initiatives implemented by the company regarding the closure of its mine and to examine the perceptions of residents from each soum regarding the company's closure plans.

Exploratory and descriptive methods were adopted as part of the research design. An exploratory study can be described as aspiring to revealthe situation at hand, and its main aims are to inquire about and assess the phenomena in a new light. A descriptive study in turn, can be seen as portraying a meticulous and accurate profile of persons, events or situations (Saunders et al., 2007). Additionally, due to the qualitative nature of the research, this study can also be classified as having a participant-observer approach since data collection was also drawn based on the researcher's observations during the gathering of the field data. Given that the researcher was embedded in the environment where the events and phenomena to be analyzed were spontaneously taking place (Yin, 2011; Spradley, 1980), employing a participant-observer approach can function as an effective strategy for capturing nuances, subtleties and patterns of phenomena that would not be possible using different methods of investigation.

The Socio-Economic Mine Closure (SEMC) Framework was used as a guidethrough which to build the structured surveys, which in turn wereused for assessing company performance and capturing and understanding local government and community perceptions with regard to a broad range of topics that include governance, transparency, community participation, communication, local economic development, planning, monitoring and evaluation, etc. 
The first steps towards understanding BGC's history, policies and procedures involved conducting a thorough review of the company's website as well as an examination of BGC's annual reports and internet publications. Additionally, a series of semi-structured in-depth interviews were scheduled with some of the company's management staff. Field trips to Mandal and Bayangol were organized. During these field trips, interviews and group sessions were held with government officials, company representatives and community members. A total of 29 interviews were held and 6 group sessions took place in the two soums. In total, 80 people were directly involved in the research, either through participating in one-on-one semi-structured in-depth interviews, group discussions, or by filling out the survey. In addition to the semi-structured interviews and the group sessions, a survey containing an average of 100 questions was distributed to three distinct groups: BGC, community and government. The survey was structured considering the elements and sub-elements found within the SEMC Framework, and an 11-point (0 to 10) Likert scale, was included. The Average (AV) of the responses was used to summarize the data. Additionally, Standard Deviation (DV) was also conducted to show variability or the distribution of the responses, helping in the assessment of how far the responses to the questions varied from the average.A lower average index indicated that people perceived that a specific situation needed to be improved, and higher scores suggested that individuals perceived a specific situation as positive.

\subsection{Analysis of the Results}

Planning, in the context of mine closure, refers to undertaking a baseline study that would include inventorying community assets, and gaining an understanding of the potential social and economic impacts that closing a mine would have on all stakeholders, particularly the local communities. Additionally, planning entails the process of developing a collective vision of how the community will look like after the mine has closed down. These steps would be followed by the creation of design projects that would be developed and implemented by the community. The results of these projects would then be measured through a participatory process in consideration of a set of performance indicators that had been jointly developed by all the stakeholders. Finally, the planning process requires that financial and technical resources are made available.

The overall interview results from the community indicate that people believe that BGC wants to leave a positive legacy after the mine has been shut down. However, concerns were raised regarding the belief that neither the local government nor the local citizens are fully aware of the company's closure plan. BGC is present in the community and maintains a close relationship with the soum government. Furthermore, Boroo participates in the Joint Working Group (JWG) whose goal is to collectively decide where to invest the Soum Development Fund. However, it was revealed that many people are not aware of how the SDF works. The intent of the establishment of the SDF is to promote community wellbeing and to foster local economic development.Historically, the majority of investments made in both soums were directed towards the construction of buildings (the Governor's Building, a sports center, cultural center, and a sanatorium) and infrastructure (roads and a hospital). Relatively speaking, only a small share of the money went into investing in the promotion of local economic development. It is important to note however, that some local economic initiatives have been implemented in Tunkhel (near Gatsuurt), as in the case of a co-operative dairy factory that was created in 2012, and which engaged 20 herders from the region. A recent update on the project however reveals that the dairy factory is nowclosed due to lack of leadership.

Although local citizens have acknowledged that they benefited from the infrastructure investments made with the money donated by BGC, it is clear that there are a variety of differentperceptions regarding how the SDF should be managed and spent.Local citizens who participated in the survey were vocal in saying that neither of the soums "need another building." In fact, they suggested that what is needed is a "program that creates jobs." The survey also corroborates the findings from the interviews. When asked for their perceptions regarding whether the mining company understands the community's most critical social issues, the residents of both soums presented low scores (Bayangol $-\mathrm{AV}=4.42 ; \mathrm{SD}=3.73 /$ Mandal $-\mathrm{AV}=4.48 ; \mathrm{SD}=3.95$ ). Both communities believe that the major challenge is to figure out how to create jobs and strengthen economic activity in the region.

Low scores were also obtained regarding the communities' perceptionsaboutthe manner in which the company takes the suggestions made by the community into account. Again, very low scores were obtained from the assessment of local residents'feelingsabout whether their ideas were taken into account by the mining company. The average score for Bayangol representatives was3.08 ( $\mathrm{SD}=2.66)$. Similarly, Mandal average scores were $3.20(\mathrm{SD}=3.36)$. It is clear from both the survey results and the interviews that community members want to have their voices heard and that they would like to participate to a greater degree in the decision-making process regarding the plans for closure. 
For many years, BGC has chosen to invest in the community according to the three following approaches: donations, the Soum Development Fund (SDF) and microcredit.Donations are usually punctual, and sometimes not linked directly to the sustainable development of the communities, as in the cases when the company donated money to support a cultural event where a Mongolian student participated in an international music competition, or when money went to supporting athletes to compete abroad. Since 2006, BGC has received 403 proposals for donations and 86 were approved (TERI, 2012). On the other hand, as envisioned by the company, the SDF should be usedto promote both the wellbeing of local citizens andthe sustainable development of the communities. Although Mandal and Bayangol government officials and community representatives agree that SDF money should be spent towards promoting the sustainable development of communities, the majority of the investments made to date through the Soum Development Fund have been related to building public infrastructure that the governments are now having difficulties in maintaining. One such example is the case of the Sports Centre in Mandal, which is operating understaffed because sufficient budget has not been allocated to hiring an adequate number of staff members.

The third investment approach made by BGC is through microfinance. In relation to this, it was found that each soum has established its own rules regarding the dispersion of the microcredit funds. In Mandal, local citizens are allowed to borrow a maximum of 500,000 MNT (Note 5) ( USD \$360). This is considered to be enough money to support local citizens who want to invest the money in a home-based-business type of crop enterprise, but is limited when it comes to supporting other projects that require more resources. In Bayangol the microcredit system is more sophisticated. There are two types of loans available, one, up to 1,000,000 MNT ( USD \$700) and another one up to 5,000,000 MNT ( USD \$3,600). In the Bayangol soum, for loans of up to 1 million MNT, the decisions are made directly by the soum governor. This situation is seen by the local citizens as an issue of concern due to the lack of transparency in the process.

An arrangement to manage the microcredit funds has been made with a local bank. This arrangement includes collecting overdue payments and making sure that the original microcredit money is not depleted.In relation to amounts of up to 5,000,000 MNT, a Joint Working Group formed by 6 company representatives and 9 local authority representatives evaluates and pre-approves the projects. In these cases prospective borrowers need to comply with a more stringent set of requirements and, for the applicant to successfully receive approval for the money, the final decision is made by the local bank branch that is responsible for managing the funds. Although the interest rates in such cases are lower than market rates, the requirements imposed by the bank are quite stringent, rendering it more challenging for ordinary people to access these loans. However, the most important issue regarding governance and transparency was raised by a government official when he bluntly stated that the bank managing the USD $\$ 200.000$ microcredit fund is not too concerned about the high requirements for lending the microcredit money since the bank can offer its own money with less rigorous requirements, but with higher interest rates. This system, in addition to having a conflict of interest, defeats the purpose of microcredit, which is intended to make resources available to people who do not have access to the regular banking system.

Since 2006, 1127 micro loans have beenmade available to community members. Of these, 837 loans were disbursed in Bayangol and 290 loans were provided for residents from Zuunkharaa and Tunkhel, in Mandal (TERI, 2012). Although the population of Mandal (25,000 inhabitants) is 5 times larger than that of Bayangol (5,000 inhabitants), Mandal disbursed 4 times less loans. In terms of amount disbursed, the ratio is comparable, where Bayangol disbursed approximately 800,000,000 MNT (US \$570,000) and Mandal lent approximately $200,000,000$ MNT (US \$140,000). These numbers again raise questions regarding the effectiveness of microcredit and suggest that the program needs to be reviewed.

During the interviews, individuals from both soums criticized the microcredit system. In Mandal, people believe that 500,000 MNT (US \$350) is not enough money, while in Bayangol people say that it is too complicated to get a loan as a result of the higher requirements from the bank.As noted during the interviews with the soum Governors, BGC keeps a very positive relationship with the governments of both soums, and it is clear that the governments appreciate this and see BGC as a good partner. On the other hand, this close relationship with the local governments also provides the company with additional challenges. In fact, one of the main obstacles related to the funds provided by BGC concerns the role performed by the local governments with respect to how / where to direct the SDF moneys. People perceive that at the end of the day, the local governments from both soums are the ones making the decisions on where and how the SDF money should be invested.As pointed out earlier, the majority of SDF investments were made towards building infrastructure. During the interviews, it became evident that the local government had not planned or budgeted for the additional expenditures it would take to operate and maintain the new facilities. This is the case with regard to the Sports Centre in Mandal, where the facility remains understaffed because there is neither a budget to maintain the building nor to support 
an adequate number of employees to run the facility. Although the Sports Centre is officially a government building, some people believe that BGC should be responsible for the maintenance of the facility. This illustrates how lack of planning, budgeting and communication create negative perceptions towards both the company and the government, and attributes responsibility to BGC whereas in this case, the maintenance of the building should be a government responsibility.

\section{Conclusion}

This paper sought to assess a framework on socio-economic mine closure. To contribute to the analysis of the framework and its elements, this paper draws on data gathered from an online survey distributed to a 151 individuals. Additionally,it draws on data gathered from a case study that took place in Mongolia. These results, combined with the analysis of the data from the fieldwork, reveal that the SEMC Framework can be adopted at any phase of the mine's life cycle. Additionally, the importance and weight given to each element constituting the SEMC Framework may vary depending on contextual elements such as social, economic and political circumstances.

In relation to the results of the fieldwork and perceptions of local people regarding the company's closure activities, it is of note that despite the fact that people believe that BGC is committed in implementing a successful closure of the mine, there is clearly a need for further planning,comprehensive community engagement and a sound communication plan. Additionally, current activities taking place on the ground also need to be reviewed and perfected, as in the case of the microcredit funds and Soum Development Fund.Another important element that requires action relates to the role of local governments. The relationship between BGC and the local governments seems to be excessively close. As a result, these relationships tend to overshadow the initiatives implemented / sponsored by the company. The main example of this relates to the SDF money donated by Boroo, which has resulted in the perception that the funds have been provided solely by the government. Focusing on the development of small business enterprises seems to be a judicious strategic path for BGC to undertake, since in addition to creating jobs and income, it is also in alignment with the wishes manifested by local citizens. Finally, in order to address the challenges uncovered through the course of the study,the creation of a mine closure working group to assist in the process of easing the concerns which have been voiced and educating local residents regarding the closure process would be both helpful and advantageous. Additionally, the establishment of such a working group would likely to result in better community engagement and participation, which are also key to the process of successfully closing a mine.

\section{References}

Australian Government - Department of Industry, Tourism and Resources. (2006). Mine Closure and Completion: Leading Practice Sustainable Development Program for the Mining Industry. Retrieved from http://www.industry.gov.au/resource/Documents/LPSDP/LPSDP-MineClosureCompletionHandbook.pdf

Centerra Gold. (2012). Boroo Production and Reserves. Retrieved December 3, 2013, from http://www.centerragold.com/operations/production-and-reserves-0

Chaloping-March, M. (2008). Managing the Social Impacts of Mine Closure: Mining and Communities in Benguet, Northern Philippines. School of Philosophy, Anthropology and Social Inquire, The University of Melbourne, Australia August 2008, PhD Thesis.

Clark, A. L., \& Clark, J. C. (1999). An International Overview of Legal Frameworks for Mine Closure. PACRIM Resource Development, Kailua, Hawaii.

Dodge, R., Daly, A., Huyton, J., \& Sanders, L. (2012). The challenge of defining wellbeing. International Journal of Wellbeing, 2(3), 222-235. http://dx.doi.org/10.5502/ijw.v2i3.4

Frank, F., \& Smith, A. (1999). The Community Development Handbook: A Tool to Build Community Capacity. Human Resources Canada.

Homan, M. (2004). Promoting community change: Making it Happen in the Real World (3rd ed.). Pacific Grove, CA: Brooks/Cole Publishing.

ICMM (International Council on Mining and Metals). (2008). Planning for Integrated Mine Closure: Toolkit. Retrieved Jan. 5, 2015, from http://www.icmm.com/page/9566/icmm-publishes-closure-toolkit

Kemp, D., Clark, P., \& Zhang, T. (2008). Estimating Socio-Economic Impacts of Mine Closure. Research Paper No. 8. Centre for Social Responsibility in Mining (CSRM).

Maser, C. (1997). Sustainable Community Development: Principles and Concepts. Delray Beach, Florida: St. Lucie Press. 
Roberts, S., \& Veiga, M. (2000). Filling the Void: The Changing Face of Mine Reclamation in the Americas. Mine Closure: Iberoamerican Experiences. Rio de Janeiro.

Saunders, M., Lewis, P., \& Thornhill, A. (2007). Research Methods for Business Students (4th ed.). Harlow, UK: Prentice Hall.

Spradley, J. P. (1980). Participant Observation. New York: Holt, Rinehart, and Winston.

TERI (Training Evaluation Research Institute). (2012). Assessment of the Community Investment of Boroo Gold: 2006-2011. Not Published Report.

van Zyl, D. (2010). Keynote Speaker Presentation at the VI Brazilian Congress of Open Pit and Underground Mine Closure. Belo Horizonte, Brazil - August 3-5.

Veiga, M., Scoble, M., \& McAllister, M. L. (2001). Mining with Communities. Resources Forum, 25(3), 191-202. http://dx.doi.org/10.1111/j.1477-8947.2001.tb00761.x

Yin, R. K. (2010). Qualitative Research from Start to Finish. The Guilford Press.

Centerra Gold. (2009). Fact Sheets. Retrieved August 16, 2011, from http://www.centerragold.com/properties/boroo/

\section{Notes}

Note 1. e.g. Equator Principles, ICMM Community Development Toolkit, Towards Sustainable Mining (TSM), MMSD 7 Questions to Sustainability, ICMM Planning for Integrated Mine Closure and ICMM 10 Principles

Note 2. The numbers in parenthesis indicate the number of responses received on the online survey by category.

Note 3. Bagh is a subdivision of a Soum.

Note 4. Soum is the equivalent of a county/district.

Note 5. Mongolian Tugrik

\section{Copyrights}

Copyright for this article is retained by the author(s), with first publication rights granted to the journal.

This is an open-access article distributed under the terms and conditions of the Creative Commons Attribution license (http://creativecommons.org/licenses/by/3.0/). 